\title{
Lance Design for Argon Bubbling in Molten Steel
}

\author{
Servando De la Cruz, Miguel A. Barron, Dulce Y. Medina, Joan Reyes \\ Departamento de Materiales, Universidad Autonoma Metropolitana Azcapotzalco, Mexico City, Mexico \\ Email: bmma@correo.azc.uam.mx
}

How to cite this paper: De la Cruz, S. Barron, M.A., Medina, D.Y. and Reyes, J. (2020) Lance Design for Argon Bubbling in Molten Steel. World Journal of Engineering and Technology, 8, 317-328. https://doi.org/10.4236/wjet.2020.83025

Received: June 1, 2020

Accepted: July 21, 2020

Published: July 24, 2020

Copyright (c) 2020 by author(s) and Scientific Research Publishing Inc. This work is licensed under the Creative Commons Attribution International License (CC BY 4.0).

http://creativecommons.org/licenses/by/4.0/

\section{(c) (i) Open Access}

\begin{abstract}
Three lance designs for argon bubbling in molten steel are presented. Bottom bubbling is considered too. Geometries considered are straight-shaped, T-shaped, and disk-shaped. The bubbling behavior of these lances is analyzed using Computational Fluid Dynamics, so transient three dimensional, isothermal, two-phase, numerical simulations were carried out. Using the numerical results, the bubble distribution and the open eye area are analyzed for the considered lance geometries. The plume volume is calculated from the open eye area and the lance immersion depth using geometrical considerations. Among the three lance designs considered, disk-shaped lance has the bigger plume volume and the smaller mixing time. As the injection lance is deeper immersed, the power stirring is increased and the mixing time is decreased.
\end{abstract}

\section{Keywords}

Bottom Injection, Bubble Plume, Computational Fluid Dynamics, Lance Design, Molten Steel, Open Eye

\section{Introduction}

Homogenization of temperature and composition of molten steel requires proper stirring, which is frequently achieved by means of argon gas bubbling given that momentum transfer occurs from argon bubbles to molten steel [1]. Besides, argon bubbling is employed to degassing of molten steel, desulphurization, removal of undesirable nonmetallic inclusions, change of inclusion morphology, enhancement of chemical reaction rate and mass transfer, and so on [2]. Argon injection in molten steel is carried out by submerged lance injection or bottom injection methods [3], as is depicted in Figure 1. When argon is injected in molten steel through a submerged lance or a porous plug located at the bottom of the ladle, the gas jet breaks up into bubbles. The rising bubbles break the up- 
per slag layer and create an open eye in the slag [4]. At low gas flow rates, discrete bubbles form at the plug exit, but at higher flow rates bubbles coalesce at the nozzle itself and assume a large size before detachment [5].

Open eye formation, plume characteristics, fluid dynamics of molten steel and slag behavior are topics that are frequently addressed by researchers in the last two decades. Cold physical modeling and Computational Fluid Dynamics simulations are commonly employed as tools for the analysis [6]. The effect of the gas flow rate on the fluid flow and open eye formation is studied in [4] using a water model. A numerical simulation of eye formation and slag entrapment in a ladle with bottom injection is reported in [7]. The mechanism of inclusion removal around the open eye is studied in [8].

Related to plume structure and characteristics, in [9] an expression is proposed for the buoyant force in the bubble plume. Besides, an equation is derived for the vertical acceleration of liquid in the plume, which is directly proportional to the injected gas flow rate and inversely proportional to the immersion depth. In [10] an expression for estimating the plume rise velocity in bubble-stirred ladle systems was derived. It is shown that the plume velocity in such systems is related to the ladle operating parameters: molten steel depth, ladle radius, and gas flow rate. A Large-Eddy Simulation model is employed in [11] to quantify the impact of the bubble size, the nozzle diameter and the gas flow rate on the properties of bubble plumes, such as the plume's width, centerline velocity, and mass flux.

Recent papers have been published on fluid dynamics in gas stirred ladles, e.g. [12]. In [13] flow structures of molten steel during stirring operations with argon injection are studied through physical and mathematical models. Emphasis is made on the turbulent conditions near the metal-slag interface since this region is important for mass transfer and inclusions capture by the slag. In [14] [15] the Euler-Euler and Euler-Lagrange modeling approaches were applied to simulate the multiphase flow in gas-stirred ladles. A multi-scale mathematical model to simulate the multiphase flow in ladles, which captures large phase interfaces and eddies is presented in [16].

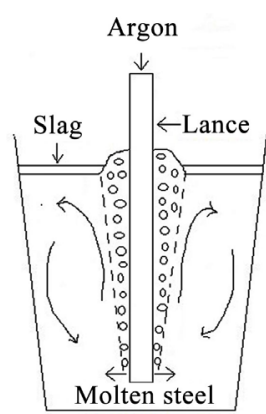

(a)

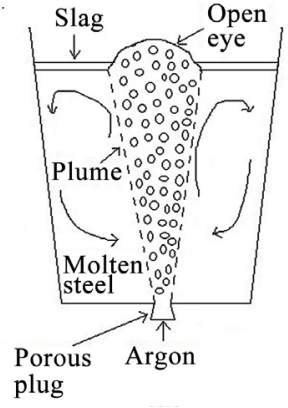

(b)

Figure 1. Methods for argon bubbling in molten steel. (a) Submerged lance injection, (b) bottom injection. 
In [17] a rotary lance is proposed and tested using a cold water model. The mixing time of the water bath stirred by gas injection was determined by an electrical conductivity method. Effects of the gas flow rate, the rotation speed and the bath depth on the mixing time were examined. It is reported that the effect of the gas flow rate on the mixing time becomes significant for high lance immersion depths and low rotation speeds. In [18] seven different lance configurations were proposed to determine the most efficient design using physical and mathematical modeling approach. A new curved port lance was designed by the authors, and this lance yields uniform and swirling flow profile inside the ladle without rotating the lance. Injection through the new lance increased the residence time of the particles and reduced the dead zones in the molten steel volume. A physical and mathematical study on gas injection in water using convergent-divergent nozzles is presented in [19]. Different geometries were employed and the plume characteristics were obtained by means of in-line pressure measurements. In [20] a scale water model of an industrial gas-stirred ladle with an eccentric porous plug at the bottom is used to study the impact of different injector designs on mixing at constant flow rate.

Unfortunately, few works have been published related to lance design. In this work three lance configurations for argon bubbling in molten steel are designed and presented. Bottom bubbling is considered too. Geometries considered are straight-shaped, T-shaped, and disk-shaped. The bubbling behavior of these lances is analyzed using Computational Fluid Dynamics, and transient three dimensional, isothermal, two-phase, numerical simulations were carried out. The open eye area, the volume plume and the plume volume fraction are quantified and compared maintaining constant the gas flow rate.

\section{Mathematical Model}

Computational Fluid Dynamics (CFD) [21] was employed to study the fluid flow in the multiphase system formed by molten steel and argon. Slag is not considered. The injection process is here considered isothermal. The equations of continuity and momentum [22], the Volume of Fluid (VOF) model for multiphase flow [23] and the classical K- $\varepsilon$ model for turbulence [24] were employed in the CFD simulations. The boundary conditions for $\mathrm{K}$ and $\varepsilon$ in the lance nozzles were determined in accordance with those suggested in [25] using the inlet velocity as parameter, which was determined from the expression

$$
v_{\text {in }}=\frac{4 Q_{g}}{\pi d_{n}^{2} N_{n}}
$$

where $v_{i}$ is the inlet velocity, $Q_{g}$ is the gas flow rate, $d_{n}$ is nozzle diameter, and $N_{n}$ is the number of nozzles in the lance head. $Q_{g}$ was kept constant irrespective of the lance design.

Stirring power can be determined using the empirical correlation reported in [26] for gas injection through a straight-shaped lance: 


$$
\dot{\varepsilon}=14.23\left(\frac{Q_{g} T_{m}}{W_{m}}\right) \log \left(\frac{1+H}{1.48 P_{0}}\right)
$$

where $\dot{\varepsilon}$ is the stirring power (W tonne $\left.\mathrm{W}^{-1}\right), Q_{g}$ is the gas flow rate $\left(\mathrm{Nm}^{3} \cdot \mathrm{min}^{-1}\right)$, $T_{m}$ is the molten steel temperature $\left({ }^{\circ} \mathrm{K}\right), W_{m}$ is the molten steel weight (tonne), $H$ is the lance immersion depth $(\mathrm{m})$, and $P_{0}$ is the gas pressure at the bath surface (atm). Besides, for the above lance, the mixing time is determined from [26],

$$
\tau_{m}=116(\dot{\varepsilon})^{-1 / 3} D^{5 / 3} H^{-1}
$$

where $\tau_{m}$ is the mixing time (s), and $D$ is the ladle diameter (m).

Residence time of the bubbles in the molten steel bath can be roughly estimated considering that bubbles have a vertical ascending trajectory:

$$
\tau_{r}=\frac{H}{v_{b}}
$$

where $\tau_{r}$ is the residence time, and $v_{b}$ is the bubble rise velocity. This last variable is estimated from the Stoke's Law [5]:

$$
v_{b}=\frac{g\left(\rho_{m}-\rho_{g}\right) d_{b}^{2}}{18 \mu_{m}}
$$

where $g$ is the gravity acceleration, $\rho_{m}$ and $\rho_{g}$ are the densities of molten steel and injection gas, respectively, $d_{b}$ is the bubble diameter, and $\mu_{m}$ is the molten steel viscosity. The bubble diameter depends, among others, on the nozzle diameter, the gas flow rate, and the physical properties of molten steel. At low gas flow rates the bubble diameter can be estimated from the expression [27]

$$
d_{b}=\left(\frac{6 d_{n} \sigma_{m}}{g\left(\rho_{m}-\rho_{g}\right)}\right)^{1 / 3}
$$

where $\sigma_{m}$ is the surface tension of molten steel.

It can be assumed that the plume is a two-phase (molten steel and gas bubbles) region in the form of an inverted cone, being its height the lance immersion depth $(H)$ and being its top diameter the diameter of the open eye. Then the plume volume $\left(V_{p}\right)$ can be estimated as the volume of a truncated cone:

$$
V_{p}=\left(\frac{1}{12}\right) \pi H\left(d_{1}^{2}+d_{2}^{2}+d_{1} d_{2}\right)
$$

where $d_{1}$ is the plume diameter at the injection point, and $d_{2}$ is the diameter of the open eye at the molten steel surface. The first one is obtained here from trigonometry and lance immersion depth, and the second one is determined from CFD simulations. For bottom injection $d_{1}=0$.

As the plume is composed of molten steel and gas bubbles, the gas content of the plume depends on the bubble diameter and the number of bubbles in the plume. The volume fraction of the plume $\left(x_{p}\right)$ is the quotient between the plume volume and the molten steel volume: 


$$
x_{p}=\frac{V_{p}}{V_{m}}
$$

The volume fraction of the plume plays an important role in the gas stirring efficiency given that, generally speaking, as $x_{p}$ is increased the momentum transfer is increased, the stirring power is increased, and the mixing time is decreased $[5]$.

\section{Numerical Solution and Simulations}

To numerically solve the momentum, continuity, turbulence and VOF model, CFD software was employed. Transient, isothermal, two-phase (molten steel and argon) three-dimensional computer simulations were carried out using a time step of $0.001 \mathrm{~s}$. Slag was not considered. The geometric model of the ladle was meshed in 99,000 trilateral cells and the ladle physical dimensions are shown in Figure 2. In the computer simulations three head lance designs were considered, namely straight, T-shaped, and disk-shaped, as is shown in Figure 3. Besides the bottom injection was simulated too.

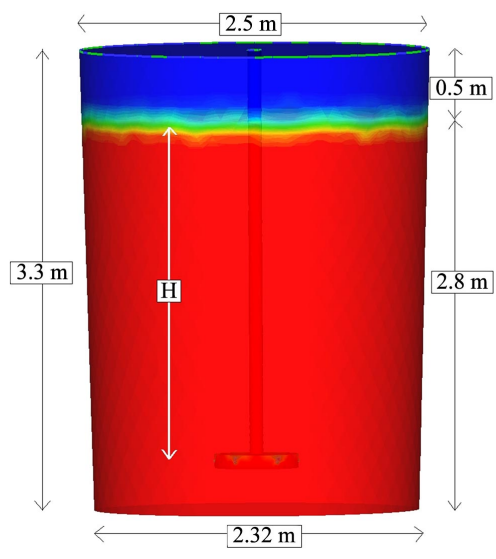

Figure 2. Physical dimensions of the considered ladle. Red phase is molten steel, blue phase is argon.

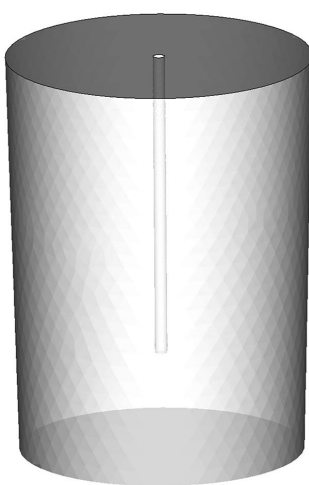

(a)

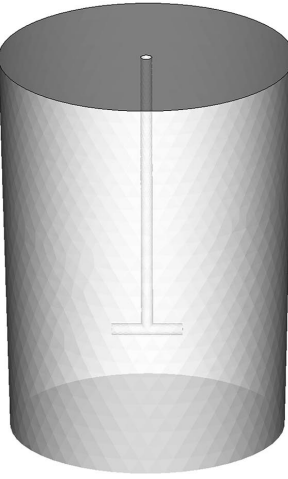

(b)

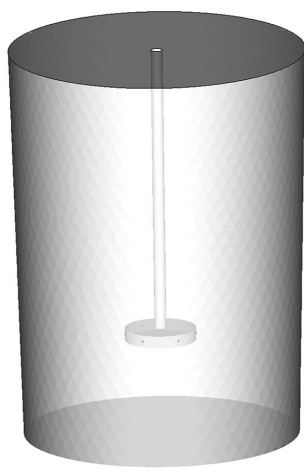

(c)

Figure 3. Considered designs of the injection lance: (a) straight-shaped, (b) T-shaped, (c) disk-shaped. 
The bottom injection has just one nozzle. The straight-shaped and the T-shaped lance have two nozzles, whereas the disk-shaped lance has six nozzles. The diameter of the lance nozzles was $0.02 \mathrm{~m}$. The molten steel depth was kept at $2.8 \mathrm{~m}$, and a lance immersion depth of $2.5 \mathrm{~m}$ was considered. The inlet velocity in each nozzle was adjusted in order to keep constant the gas flow rate at 0.377 $\mathrm{Nm}^{3} \cdot \mathrm{min}^{-1}$. In this way, the inlet velocity for the bottom nozzle was $20 \mathrm{~m} \cdot \mathrm{s}^{-1}$, for the straight-shaped and T-shaped nozzles were $10 \mathrm{~m} \cdot \mathrm{s}^{-1}$, and for the disk-shaped was $3.33 \mathrm{~m} \cdot \mathrm{s}^{-1}$. The physical properties of the involved phases are shown in Table 1. Besides, Table 1 shows the values of the operational parameters employed in the numerical simulations, which approximately correspond to an industrial ladle, as it is reported in [1] and [5].

\section{Results and Comments}

Numerical files obtained from CFD simulations were post-processed in order to analyze the characteristics of the flow dynamics for each of the lance design or bubbling method considered. Three aspects are reported: bubble distribution, streamlines of bubbles in molten steel, and phase distribution. Finer resolution of bubble geometry and size was not possible given the rather coarse mesh employed in the computer simulations. Working with a finer mesh was not possible for the present authors given the limitations of the available hardware. However, in spite of this disadvantage, some valuable information is obtained.

Table 1. Values of the parameters employed in the numerical simulations.

\begin{tabular}{|c|c|}
\hline Parameter & Value \\
\hline Molten steel density & $7100 \mathrm{~kg} \cdot \mathrm{m}^{-3}$ \\
\hline Molten steel temperature & $1773.15^{\circ} \mathrm{K}$ \\
\hline Molten steel viscosity & $0.0067 \mathrm{~kg} \cdot \mathrm{m}^{-1} \cdot \mathrm{s}^{-1}$ \\
\hline Molten steel surface tension & $1.69 \mathrm{~N} \cdot \mathrm{m}^{-1}$ \\
\hline Molten steel weight & 90 tonnes \\
\hline Molten steel volume & $12.63 \mathrm{~m}^{3}$ \\
\hline Molten steel depth & $2.8 \mathrm{~m}$ \\
\hline Gas density & $1.18 \mathrm{~kg} \cdot \mathrm{m}^{-3}$ \\
\hline Gas pressure at the molten steel surface & $1 \mathrm{~atm}$ \\
\hline Nozzles diameter & $0.02 \mathrm{~m}$ \\
\hline Lance diameter & $0.1 \mathrm{~m}$ \\
\hline Lance immersion depth & $2.5 \mathrm{~m}$ \\
\hline Length of $\mathrm{T}$ head & $0.6 \mathrm{~m}$ \\
\hline Disk diameter & $0.6 \mathrm{~m}$ \\
\hline Gas flow rate & $0.377 \mathrm{Nm}^{3} \cdot \mathrm{min}^{-1}$ \\
\hline Nozzles in normal lance & 2 \\
\hline Nozzles in $\mathrm{T}$ lance & 2 \\
\hline Nozzles in disk lance & 6 \\
\hline
\end{tabular}


Figures 4-7 show the bubble distribution, the streamlines in the molten metal, and the phase distribution for the straight-shaped, T-shaped, disk-shaped, and bottom injection configurations, respectively. These figures correspond to an immersion depth of $2.5 \mathrm{~m}$. For the gas flow rate considered, in the straightshaped lance bubbles ascend vertically almost stuck to the lance with low lateral dispersion, as is seen in Figure 4(a) and Figure 4(c). This causes a reduced open eye area, as is observed in Figure 8(a) and Table 2. A comparison between Figure 4(a) and Figure 5(a) suggests that the T-shaped lance causes a lateral dispersion greater than that caused by the straight-shaped lance. Then a larger open eye area it would be expected for the T-shaped lance, as is corroborated in Figure $8(\mathrm{~b})$ and Table 2.

Table 2. Estimated values of plume parameters.

\begin{tabular}{cccc}
\hline Lance design & Open eye area, $\mathrm{m}^{2}$ & Plume volume, $\mathrm{m}^{3}$ & Plume volume fraction \\
\hline Straight-shaped & 0.0619 & 0.0577 & $0.4568 \times 10^{-2}$ \\
T-shaped & 0.1011 & 0.0942 & $0.7457 \times 10^{-2}$ \\
Disk-shaped & 0.1490 & 0.1389 & $1.0995 \times 10^{-2}$ \\
Bottom injection & 0.1089 & 0.1017 & $0.8051 \times 10^{-2}$ \\
\hline
\end{tabular}

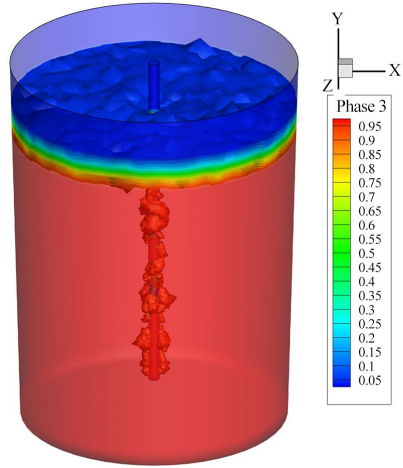

(a)

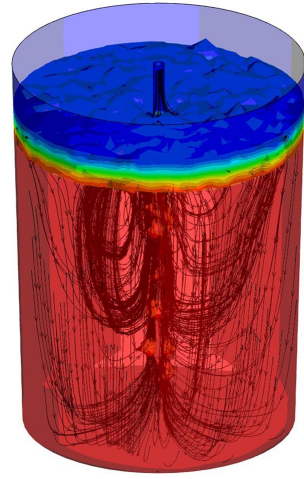

(b)

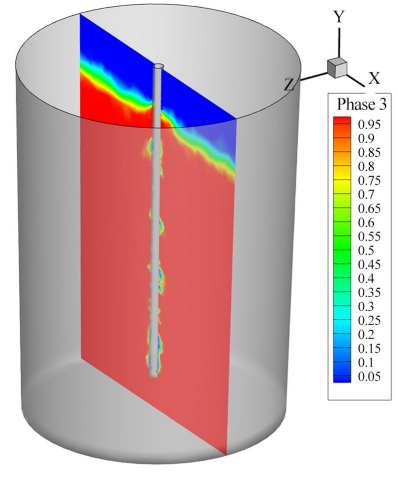

(c)

Figure 4. Numerical results for straight-shaped lance. (a) Argon bubbles, (b) streamlines, (c) phases. Red phase is molten steel, blue phase is argon.

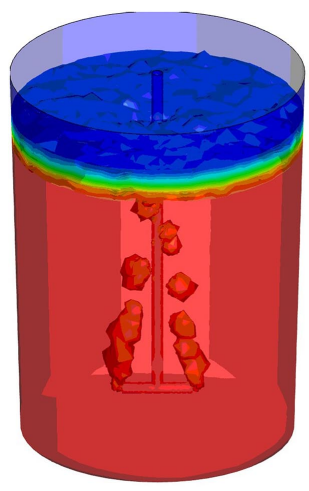

(a)
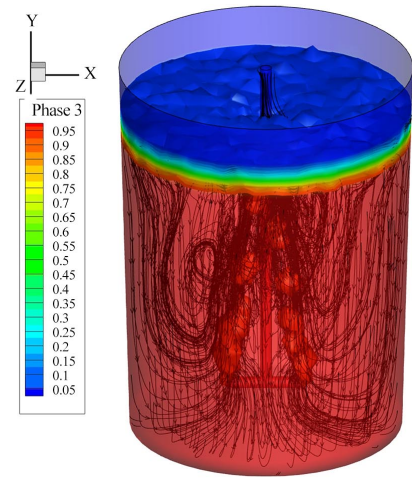

(b)

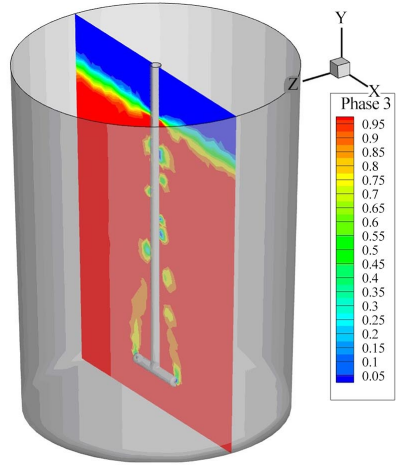

(c)

Figure 5. Numerical results for T-shaped lance. (a) Argon bubbles, (b) streamlines, (c) phases. Red phase is molten steel, blue phase is argon. 


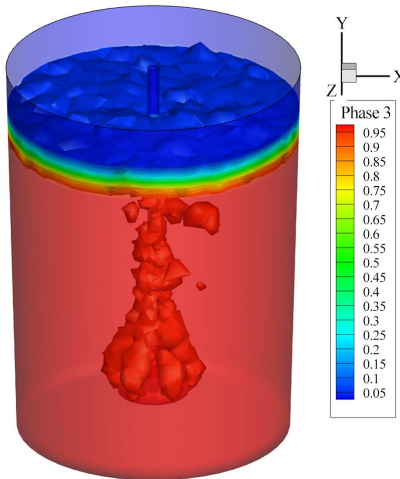

(a)

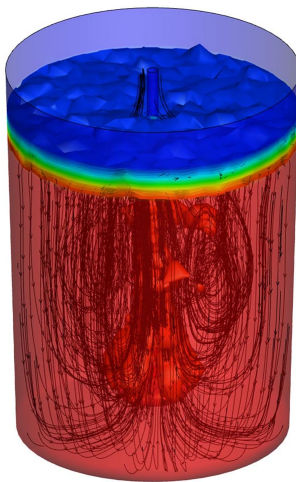

(b)

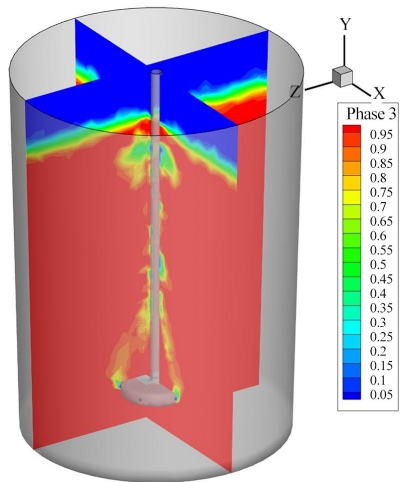

(c)

Figure 6. Numerical results for disk-shaped lance. (a) Argon bubbles, (b) streamlines, (c) phases. Red phase is molten steel, blue phase is argon.

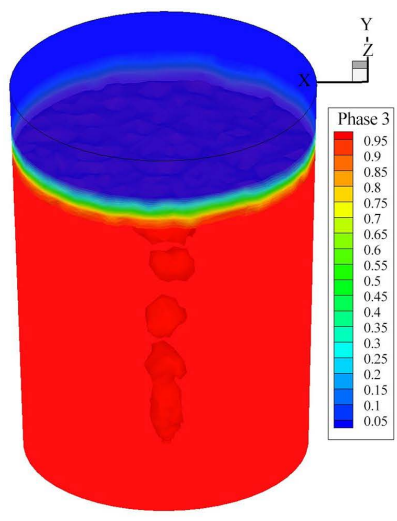

(a)

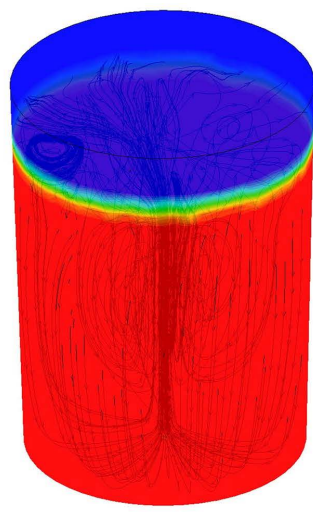

(b)

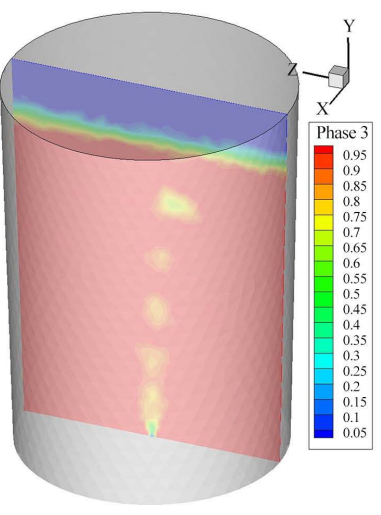

(c)

Figure 7. Numerical results for bottom injection. (a) Argon bubbles, (b) streamlines, (c) phases. Red phase is molten steel, blue phase is argon.

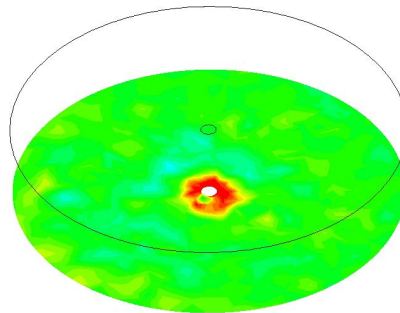

(a)

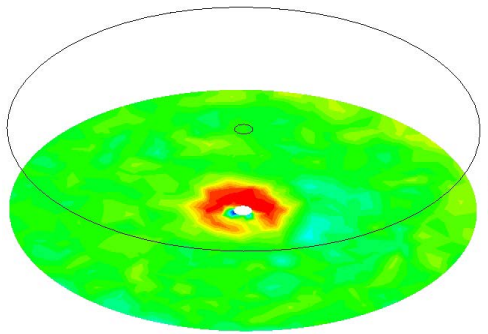

(c)

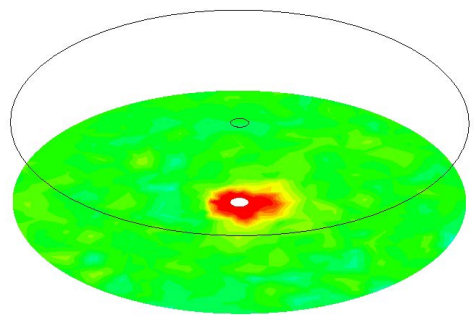

(b)

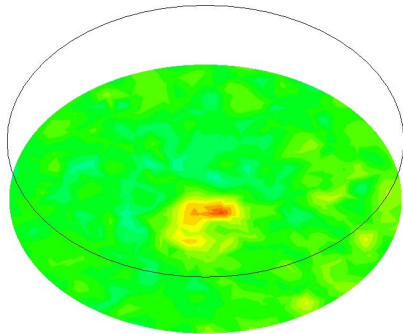

(d)

Figure 8. Open eye (red color) for the considered lance designs. (a) straight-shaped, (b) T-shaped, (c) disk-shaped, (d) bottom injection. 
Results for the bottom injection method are presented in Figure 7. This method has a similar behavior to that of the T-shaped design in terms of the open eye area, as is seen in Table 2. In accordance with Figure 6(a) and Figure 6(c), among the designs considered here, the disk-shaped lance exhibits the widest bubble dispersion. This is due to the large number of nozzles and its circular distribution along the lance head. According to the above, the disk-shaped lance presents the largest open eye area, the largest plume volume, and the largest plume volume fraction, as is shown in Table 2 . As the plume volume and the plume volume fraction are related to large stirring power and small mixing time, then the disk-shaped lance presents, among the considered designs, the best performance.

From a broad point of view, the flow patterns for the whole set of lances are similar, as is observed in Figures 4(b)-7(b). Generally speaking, recirculatory streamlines are formed in the bulk melt. However, more detailed studies are required to disclose the particularities of the flow patterns induced by each of the lance designs. Flow patterns were not an objective of the present work. It is important to recognize that the flow pattern and the interaction between molten steel and slag at the molten metal surface play an important role in the capture of non-metallic inclusions by the slag.

The stirring power and the mixing times for the straight-shaped lance as function of the lance immersion depth are shown in Figure 9 and Figure 10. It is appreciated that the lance immersion depth increases the stirring power and decreases the mixing time, as is reported in [1]. The bottom injection method minimizes the mixing time due to its large immersion depth, however this method, in accordance to Table 2, yields a lower plume volume and a lower plume volume fraction than the disk-shaped lance.

\section{Conclusions}

Three lance designs were studied for stirring of molten steel by means of argon bubbling: straight-shaped, T-shaped and disk-shaped. Bottom injection was considered too. Three-dimensional transient and isothermal two-phase Computational Fluid Dynamics simulations were carried out to compare the lances performance in terms of bubble distribution, plume volume and open eye area.

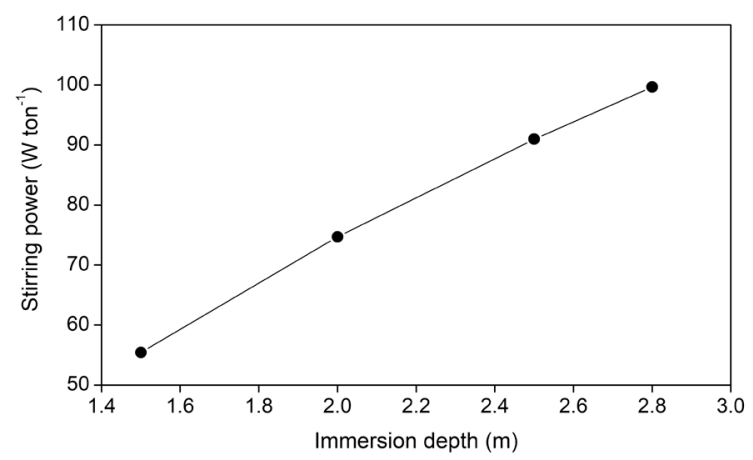

Figure 9. Stirring power as function of the immersion depth for the straight-shaped lance. 


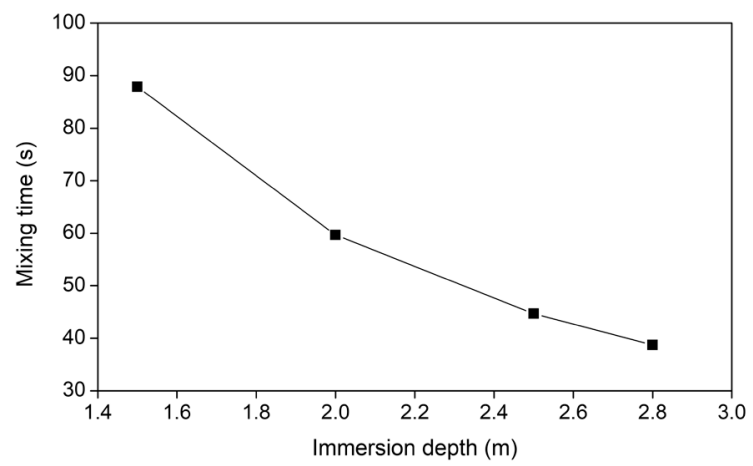

Figure 10. Mixing time as function of the immersion depth for the straight-shaped lance.

Under the considered conditions (gas flow rate of $0.337 \mathrm{Nm}^{3} \cdot \mathrm{min}^{-1}$, immersion depth of $2.5 \mathrm{~m}$, molten steel depth of $2.8 \mathrm{~m}$, nozzle diameter of $0.02 \mathrm{~m}$, weight of molten steel of 90 tonnes), and from the computer simulations results the following conclusions arise:

For argon bubbling, the lance configuration affects the bubble distribution, the plume volume and the open eye area in the molten steel. Under the considered conditions the plume volume and the open eye area of the T-shaped lance are similar to those of the bottom injection method. Among the three lance designs considered, disk-shaped lance has the bigger plume volume and the smaller mixing time. As the injection lance is deeper immersed the power stirring is increased and mixing time is decreased. Given that the mesh employed in the current simulations is relatively coarse, it is suggested that future work must be carried out considering finer meshing and cold model comparison.

\section{Conflicts of Interest}

The authors declare no conflicts of interest regarding the publication of this paper.

\section{References}

[1] AISE (1998) The Making, Shaping and Treating of Steel. AISE Steel Foundation, Pittsburg.

[2] https://www.ispatguru.com/ladle-metallurgy

[3] Ghosh, A. and Chatterjee, A. (2008) Ironmaking and Steelmaking. Theory and Practice. PHI Learning, New Delhi.

[4] Ramasetti, E.K., Visuri, V.V., Sulasalmi, P. and Fabritius, T. (2018) A CFD and Experimental Investigation of Slag Eye in Gas Stirred Ladle. Journal of Flow, Heat and Mass Transfer, 5, 78-86. https://doi.org/10.11159/ffhmt18.148

[5] Ghosh, A. (2001) Secondary Steelmaking. Principles and Applications. CRC Press, Boca Raton. https://doi.org/10.1201/9781420042313

[6] Liu, Y., Ersson, M., Liu, H., Jonsson, P.G. and Gan, Y. (2019) A Review of Physical and Numerical Approaches for the Study of Gas Stirring in Ladle Metallurgy. Metallurgical and Materials Transactions B, 50, 555-577. https://doi.org/10.1007/s11663-018-1446-x 
[7] Liu, W., Tang, H., Yang, S., Wang, M., Li, J., Liu, Q. and Liu, J. (2018). Numerical Simulation of Slag Eye Formation and Slag Entrapment in a Bottom-Blown Argon-Stirred Ladle. Metallurgical and Materials Transactions B, 49, 2681-2691. https://doi.org/10.1007/s11663-018-1308-6

[8] Kang, Y.J., Yu, L. and Sichen, D. (2007) Study of Inclusion Removal Mechanism around Open Eye in Ladle Treatment. Ironmaking and Steelmaking, 34, 253-261. https://doi.org/10.1179/174328107X168101

[9] Bernard, R.S., Maier, R.S. and Falvey, H.T. (2000) A Simple Computational Model for Bubble Plumes. Applied Mathematical Modeling, 24, 215-233. https://doi.org/10.1016/S0307-904X(99)00030-X

[10] Mazumdar, D. (2002) On the Estimation of Plume Rise Velocity in Gas-Stirred Ladles. Metallurgical and Materials Transactions B, 33, 937-941. https://doi.org/10.1007/s11663-002-0080-8

[11] Fraga, B. and Stoesser, T. (2016) Influence of Bubble Size, Diffuser Width, and Flow Rate on the Integral Behavior of Bubble Plumes. Journal of Geophysical Research: Oceans, 121, 3887-3904. https://doi.org/10.1002/2015JC011381

[12] Irons, G., Senguttuvan, A. and Krishnapisharody, K. (2015) Recent Advances in the Fluid Dynamics of Ladle Metallurgy. ISIJ International, 55, 1-6. https://doi.org/10.2355/isijinternational.55.1

[13] Morales, R.D., Calderon-Hurtado, A., Chattopadhyay, K. and Guarneros, J. (2020) Physical and Mathematical Modeling of Flow Structures of Liquid Steel in Ladle Stirring Operations. Metallurgical and Materials Transactions B, 51, 628-648. https://doi.org/10.1007/s11663-019-01759-X

[14] Cao, Q. and Nastac, L. (2018) Mathematical Investigation of Fluid Flow, Mass Transfer, and Slag-Steel Interfacial Behavior in Gas Stirred Ladles. Metallurgical and Materials Transactions B, 49, 1388-1404. https://doi.org/10.1007/s11663-018-1206-y

[15] Duan, H., Zhang, L., Thomas, B.G. and Conejo, A. (2018) Fluid Flow, Dissolution, and Mixing Phenomena in Argon-Stirred Steel Ladles. Metallurgical and Materials Transactions B, 49, 2722-2743. https://doi.org/10.1007/s11663-018-1350-4

[16] Li, L., Li, B. and Liu, Z. (2017) Modeling of Gas-Steel-Slag Three-Phase Flow in Ladle Metallurgy: Part II. Multi-Scale Mathematical Model. ISIJ International, 57, 1980-1989. https://doi.org/10.2355/isijinternational.ISIJINT-2017-069

[17] Diaz, M., Iida, T., Kimarov, S.V. and Sano, M. (1995) Mixing Characteristics under Gas Injection through Rotary Lance Submerged in Liquid Bath. ISIJ International, 35, 464-471. https://doi.org/10.2355/isijinternational.35.464

[18] Tripathi, P., Kumar, D.S., Sah, R. and Sekhar, V.R. (2016) An Improved Lance Design for Hot Metal Desulphurisation. Ironmaking and Steelmaking, 44, 1-9.

[19] Arellano, A.I., Jaramillo, D., Barron, M.A. and Plascencia, G. (2014) Momentum Transfer in Submerged Gas Injection using Convergent-Divergent Nozzles. Latin American Applied Research, 44, 295-299.

[20] Gajjar, P., Haas, T., Owuso, K.B., Eickhoff, M. and Kowitwarangkul, P. (2019) Physical Study of the Impact of Injector Design on Mixing, Convection and Turbulence in Ladle Metallurgy. Engineering Science and Technology, 22, 538-547. https://doi.org/10.1016/j.jestch.2018.11.010

[21] Ferziger, J.H. and Peric, M. (1999) Computational Methods for Fluid Dynamics. Springer, Berlin. https://doi.org/10.1007/978-3-642-98037-4

[22] Bird, R.B., Stewart, W.E. and Lightfoot, E.N. (2002) Transport Phenomena. Wiley, New York. 
[23] Hirt, C.W. and Nichols, B.D. (1981) Volume of Fluid (VOF) Method for the Dynamics of Free Boundaries. Journal of Computational Physics, 39, 201-225. https://doi.org/10.1016/0021-9991(81)90145-5

[24] Launder, B.E. and Spalding, D.B. (1972) Mathematical Models of Turbulence. Academic Press, London.

[25] Thomas, B., Yuan, Q., Sivaramakhrisnan, S., Shi, T., Vanka, S.P. and Assar, M.B. (2001) Comparison of Four Methods to Evaluate Fluid Velocities in a Continuous Slab Casting Mold. ISIJ International, 41, 1262-1271. https://doi.org/10.2355/isijinternational.41.1262

[26] AISE (1998) The Making, Shaping and Treating of Steel. Steelmaking and Refining Volume. The AISE Steel Foundation, Pittsburgh.

[27] Szekely, J. (1979) Fluid Flow Phenomena in Metals Processing. Academic Press, New York. 